Table 1. INFLUENOE OF ACTINOMYCIN $D$ ON THE INSUlin-INDUCED STIMULATION OF THE BTOSYNTHDSS OF RYA AND PROTEIN IN THE ISOLATED RAT DIAPHRAGM

\begin{tabular}{|c|c|c|c|c|}
\hline \multirow{2}{*}{\multicolumn{5}{|c|}{ Actinomycin $D(10 \mu \mathrm{g} / \mathrm{ml})}}$. \\
\hline & & 0 & + & + \\
\hline Insulin $\left(10 \mu \mathrm{g} / \mathrm{ml}_{A}\right)$ Biosynthesis of $\mathrm{RN}$ & $\begin{aligned} 0 \\
0\end{aligned}$ & & & \\
\hline ATP (counts $/ \mu \mathrm{g})$ & 201 & 212 & 207 & 280 \\
\hline $\begin{array}{l}\text { RNA fraction (counts incorporated } / 100 \\
\text { mg tissue) }\end{array}$ & 1,0 & 2,040 & 26 & \\
\hline$B \quad \mathrm{I}$ & & & & \\
\hline cid pool (counts $/ \mu \mathrm{g}$ ) & 319 & 374 & 327 & \\
\hline -acid pool (counts $/ \mu$ & 66 & 7 & 69 & \\
\hline roteins (counts $/ \mathrm{mg}$ ) & 316 & 706 & 395 & \\
\hline
\end{tabular}

Table 2. InFluence of ACtinomycin $D$ AND PURomycin on the INSULin. indUCED STIMULATION OF THE Labelind OF Phosphates in the Isolated RAT DIAPHRAGM

Specific activity (percentage of extracellular or

Actinomycin $D$

(10 $\mu \mathrm{g} / \mathrm{mll}$.)

Puromycin $(500 \mu \mathrm{g} / \mathrm{m}$

Insulin $(10 \mu \mathrm{g} / \mathrm{ml}$.

phosphorus

${ }_{\mathrm{PC}}$ *

ATP

$\mathrm{ADP}$

$\begin{array}{rr}0 & \\ 0 & \\ 0 & \\ 6 & \\ 6 \cdot 9 & 6 \\ 35 \cdot 8 & 44 \\ 44.5 & 58 \cdot 5 \\ 19 \cdot 7 & 24 \cdot \\ 24 \cdot 4 & 37\end{array}$

$\begin{array}{rr}0 & + \\ 0 & \\ + & \\ 6 \cdot 2 & 7 \cdot \\ 44 \cdot 4 & 32 \cdot \\ 58.5 & 40 \cdot \\ 24 \cdot 5 & 19 \cdot 5 \\ 37 \cdot 9 & 26 .\end{array}$

$\begin{array}{rr}+ & \\ 0 & \\ 0 & \\ 7 \cdot 2 & 6 \\ 32 \cdot 7 & 53 \cdot 7 \\ 40 \cdot 2 & 68 \cdot \\ 19 \cdot 5 & 30 \cdot 2 \\ 26 \cdot 2 & 51.5\end{array}$

$\begin{array}{rr}+ & \\ 0 & + \\ + & \\ 6 \cdot 7 & 8 \cdot \\ 53 \cdot 3 & 31 \cdot \\ 68 \cdot 0 & 43 \cdot \\ 30 \cdot 2 & 17 \cdot \\ 51.5 & 16 .\end{array}$

(E) Percentage of extracellular inorganic phosphorus.

(E) Pereentage of extracellular inorganic phosphorus.
* Phosphontage of intracellular inorganic phosphorus.

+ Sum of uridine and guanosine phosphates.

Table 3. Influence of Puromycin on the Insulin-Induchd StimeLation of Protein Biosy NThesis in Isolated Rat Diaphragm A Precursor: U-14C protein hydrolysate

\begin{tabular}{|c|c|c|c|c|}
\hline Puromycin $(500 \mu \mathrm{g} / \mathrm{ml})$. & 0 & 0 & 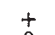 & + \\
\hline Insulin $(10 \mu \mathrm{g} / \mathrm{ml})$. & 0 & + & 0 & + \\
\hline $\begin{array}{l}\text { Extracellular amino-acid pool } \\
\text { (counts } / \mu \mathrm{g} \text { ) }\end{array}$ & 940 & 740 & 545 & 518 \\
\hline $\begin{array}{l}\text { Intracellular amino-acid pool } \\
\text { (counts } / \mu \mathrm{g})\end{array}$ & & & 152 & 131 \\
\hline Proteins (counts/mg) & $\begin{array}{r}750 \\
14 \mathrm{C}\end{array}$ & $e^{1,371}$ & 24 & \\
\hline $\begin{array}{l}\text { Incubation medium (counts } / 100 \mathrm{mg} \text { ) } \\
\text { Intracellular medium (counts } / 100 \mathrm{mg} \text { ) } \\
\text { Proteins (counts } / \mathrm{mg} \text { ) }\end{array}$ & $\begin{array}{r}7.800 \\
6 \cdot 300 \\
166\end{array}$ & $\begin{array}{r}8 \cdot 800 \\
5 \cdot 745 \\
213\end{array}$ & $\underline{-}$ & \\
\hline
\end{tabular}

Proteins (counts/mg)

The second set of conclusions concerns the mutual independence of the phenomena which have been tested. This independence is particularly striking so far as protein and RNA biosynthesis are concerned: the complete suppression of the latter has no influence whatsoever on the stimulation of the former; thus it seems difficult to conclude that the biosynthesis of a messenger RNA. could even partially mediate the action of insulin on the isolated muscle.

Hence this action seems to consist in a general stimulation of uncorrelated metabolic events; the insulininduced increase of glucose-uptake may, however, be inhibited by short pre-incubations with $N$-ethylmaleimide $^{2}$. This equally holds for the labelling of energy-rich phosphates ${ }^{10}$ and demonstrates that an interaction of insulin with specific - SH groups is a pre-requisite for its effect on the isolated muscle, the precise mechanism of which (for example, cell 'decompartmentation') remain at present a matter of speculation.
D. FBouk-Bonis
A. M. Chambaut
P. VOLFIN
H. Cratgar

Laboratoire de Chimie Biologique,

Faculté des Sciences,

96 Boulevard Raspail, Paris.

${ }^{1}$ Post, R. I., Morgan, H. E., and Park, C. R., J. Biol. Chem, 236, 269 (1961).

${ }^{2}$ Kipnis, D. M., and Cori, C. F., J. Biol. Chem., 234, 171 (1959).

${ }^{3}$ Manchester, K. L., Biochem. J., 81, 135 (1961).

4 Wool, I. G., Biochim. Biophys. Acta, 68, 28 (1963).

'Clauser, H., Volfin, P., and Eboué-Bonis, D., Gen. Comp. Endecrinul., 2,

- Jacob, F., and Monod, J., J. Mol. Biol., 3, 318 (1961). Mueller, G. C., Gorski, J., and Aizawa, Y., Proc. U.S. Nat. Acad. Sci.,

${ }^{8}$ Tata, J. R., Nature, 197, 1167 (1963).

${ }^{9}$ Cadenas, E., Kaji, H., Park, C. R., and Rasmussen, H., J. Biol. Chem., 236, PC 63 (1961).

"Volfin, P., Eboué-Bonis, D., Chambaut, A. M., and Clauser, H., Bull. soc. Chim. Biul., 45, 458 (1963).

\section{Naphthalenes in Cigarette Smoke}

IN our work on the composition of the non-methanol volatile neutral fraction of cigarette smoke we have isolated and identified the naphthalenes shown in Table 1.

$\begin{array}{lc}\text { Substance } & \text { Table 1 } \\ \text { Naphthalene } & \text { Yield * } \\ \text { 2-Methylnaphthalene } & 0 \cdot 17 \\ \text { 1-Methylnaphthalene } & 0 \cdot 50 \\ \text { 2,7-Dimethylnaphthalene } & 0 \cdot 50 \\ \text { 2,6-Dimethylnaphthalene } & 0 \cdot 26 \\ \text { 1,6-Dimethylnaphthalene } & 0 \cdot 26 \\ \text { 1,3,6-Trimethylnaphthalene } & 1 \cdot 30 \\ \text { * In } \mu \text { g/eigarette (average weight, } 1 \cdot 15 \mathrm{~g} \text { ) }\end{array}$

The naphthalenes were isolated from chromatographic fractions of cigarette smoke condensate by precipitation as complexes with $s$-trinitrobenzene. The combined complexes were decomposed and the mixture of naphthalenes obtained was separated by preparative scale gas chromatography. The individual naphthalenes were identified by comparison of ultra-violet and infra-red spectra with those of authentic specimens and by the preparation of solid derivatives. Analytical gas chromatography showed that these were the only naphthalenes present (eluted in the order shown in Table 1) except for a small shoulder appearing on the peak corresponding to 1,6-dimethylnaphthalene. 'The retention volume of this shoulder corresponded to 1,8-dimethylnaphthaleno and/or acenaphthene. Naphthalene, 2-methylnaphthalene, and possibly 1,8-dimethylnaphthalene have been detected already by ultra-violet spectroscopy ${ }^{1,2}$. Acenaphthylene, reported earlier', occurs in a later chromatographic fraction of the smoke condensate. The relatively large quantities of dimethyl- and trimothylnaphthalenes have escaped detection by methods used previously, but their presence gives an important lead to the understanding of the mode of formation of polycyclic hydrocarbons in cigarette smoke. The positions of the methyl groups indicate terpenoid precursors of these naphthalenes, and an extension of the suggested mode of thermal decomposition of isoprenoid polyolefines $\mathrm{S}^{3}$ can account fully for their formation.

R. A. W. Johnstone

P. M. QUaN

Medical Research Council Unit,

University of Exeter.

${ }_{1}$ Cooper and Lindsey, Chem. and Indust, 1260 (1954); Brit. J. Cancer, 9, 304 (1955). Gilbert and Lindsey, ibid., 10, 642, 646 (1956).

${ }^{8}$ Bonnet and Nenkomm, Helv. Chim. Acta, 39, 1724 (1956).

s Johnstone and Quan, J. Chem. Soc., 2221 (1963).

\section{Boric Acid-induced Heterogeneity of Conalbumin by Starch-gel Electrophoresis}

MuLtrple molecular forms of conalbumin', the ironbinding component of avian egg white, have been described by numerous investigators under a variety of experimental conditions. In the original purification of conalbumin, Longsworth et al. ${ }^{2}$ identified two components, the rolative proportions of which were dependent on $p H$. Afterwards, by starch-gel electrophoresis, Lush ${ }^{3}$ identified two, and occasionally three, iron-binding proteins in native egg white, as did Williams ${ }^{4}$ and Ogden et al. ${ }^{5}$. In each of these cases $^{3-5}$, the slower migrating of the two components was the more intense; in the latter investigation ${ }^{4,5} \mathrm{a}$ corresponding heterogeneity was observed in transferrin, the iron-binding protein in the serum of the animal. Thus, in the chicken, as in other species, including $\operatorname{man}^{6}$, primates ${ }^{7}$, cattlo $e^{8,8}$, bison ${ }^{10}$, horses ${ }^{11}$, and mice ${ }^{12}$, a single transferrin allele appears to determine the synthesis of moro than one molecular species of transferrin. Ultracentrifugal investigations on purified cattle transferrins indicate that the multiple bovine components do not represent a polymer series ${ }^{13}$.

Ogden et al. ${ }^{5}$ have also described a genetically determined variation in chicken serum transforrin which is 